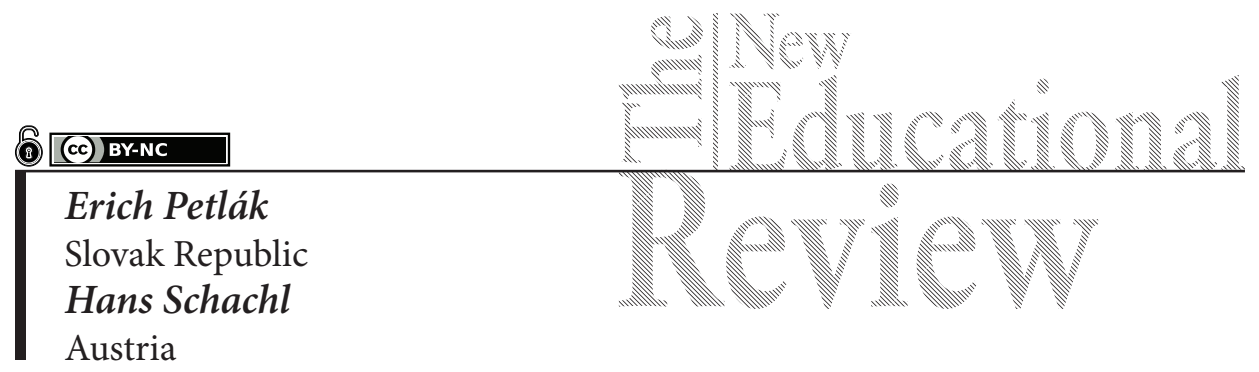

\title{
Neurodidactics and Its Perception by Teachers in Slovakia
}

DOI: 10.15804/tner.2019.57.3.13

\begin{abstract}
In our report we briefly describe the existing state and tendencies in teacher training for primary schools. It is important to state that we are implementing a vital reform effort in our educational system. If we really want to emphasize the nature of changes in our school system, we need to be focused mainly on the use of those methods by beginner teachers that are not forming just knowledge, but also leading to creative use of knowledge in learning and life.
\end{abstract}

Keywords: education, neuroscientfic, neurodidactics, research, Slovakia, emotionality

\section{Introduction}

The reality is that in the last $2-3$ decades education changed. Various innovative approaches are used in teaching, based mainly on alternative pedagogy. This pedagogy, in fact, was unknown to us in 1990 and was referred to as "unwanted Western pedagogy". The most common criticism of education is that little attention is paid to the development of pupils' creativity, little use is made of innovations in the educational process, pupils have knowledge, but they are not able to use it, there are significant differences between pupils from different social strata and so on. One way to improve the course and results of education can be the use neuroscientific knowledge in education. 


\section{Selected views of neuropedagogy and neurodidactics}

In recent years there have been many different theories of education in pedagogy. Each theory wants to contribute to improving the quality of education. This expansion is proof that pedagogy, in collaboration with other sciences, is striving to advance and reduce the discrepancy between what the school gives to the pupil and what the society demands.

One of the latest and most innovative approaches to education is a significant emphasis on the brain functions in the student's learning process. This is the area which enters into the realm of education under the terms "neuropedagogy" and "neurodidactics." Looking at literature on education, we find a lot of authors in Europe who very strongly accentuate neuroscientific views on education. They are, among others, Arnold (2002), Becker (2005), Dryden, Vos (1999), Friedrich (2005), Hermann (1990), Preiss (1998), Schachl (2006), Spitzer (2002), Ulrich (2006).

Essential requirements based on neuroscience views have been described by Caine and Caine (1997), commonly known as "brain-correct teaching". In such a teaching approach, the emphasis is placed on the importance of the brain operations in learning. If education should be effective, we need to implement it in accordance with the brain functions.

What is neuroeducation? Neuroeducation is the combination of neurosciences and pedagogy with the goal of optimizing the learning experience. This discipline seeks to understand brain functions (how our brain assimilates, codes, or remembers information) and apply this to teaching. Consequently, teachers will develop better educational methods. Human beings use an integral process when they learn something where thought, feeling, and action are all inseparable in the learning experience. With this in mind, neuroeducation concentrates on finding ways to deepen the learning process by understanding how the brain learns and adapting classroom techniques to help achieve this. (Geake, 2009)

Neurodidactics also emphasizes that the brain has an extremely great potential that is not entirely utilized by human beings. The American brain researcher, Diamond (who also studied Einstein's brain), said: "The brain is very dynamic, it changes from birth to the end of life. In a stimulating environment, it changes positively, but stagnates when not encouraged at all." (Dryden, Vos, 2003, p. 127)

Neurodidactics is a relatively young discipline that represents an inter-face between neuroscience and didactics. Based on the findings of brain research, neurodidactics provides principles and proposals for effective (brain-based) teaching and learning (Sabitzer, 2011, p. pp. 167-177) 
Learning is not just storing new knowledge in memory. In describing several aspects of the learning process in terms of the neurological research, Lorenz (2009) makes some recommendations to be taken into account, as they fundamentally change the perceptions of teaching and learning.

Table 1. Learning - a neuroscientific point of view

\begin{tabular}{|c|c|}
\hline INCORRECT APPROACH & CORRECT APPROACH \\
\hline $\begin{array}{l}\text { Judging child's abilities and IQ based } \\
\text { on their ability to read and count, the } \\
\text { child gains the experience that any } \\
\text { effort is unnecessary, loses self-confi- } \\
\text { dence and confidence in their ability. }\end{array}$ & $\begin{array}{l}\text { Let the children create a useful routine for their future } \\
\text { life so that they do not "lose" the axons (part of the } \\
\text { neuron splicing) due to lack of opportunity. Letters } \\
\text { can be learned by e.g. modelling and singing, they can } \\
\text { count on hands or count objects and so on. Discover } \\
\text { science with your hands and senses, or by an exciting } \\
\text { talk. Such a process leads not only to easier learning, } \\
\text { but also to the fact that the individual will later, in all } \\
\text { their life, reveal the essence, seek meaning in newness } \\
\text { and the like, and that way they will develop his skills. }\end{array}$ \\
\hline $\begin{array}{l}\text { If you ask pupils to learn by means of } \\
\text { memorization because it will bring } \\
\text { them success (they know the curricu- } \\
\text { lum, they will get a good grade), you } \\
\text { will not be able to work with the pupils } \\
\text { later on. }\end{array}$ & $\begin{array}{l}\text { Use your and your child's neuroplasticity and learn } \\
\text { new approaches and skills to support children - learn- } \\
\text { ers, discover that learning can be fun that you never } \\
\text { realised before. }\end{array}$ \\
\hline $\begin{array}{l}\text { If you want to activate and encourage } \\
\text { boys more by comparing them to girls, } \\
\text { it will not support good relationships } \\
\text { with the opposite sex. }\end{array}$ & $\begin{array}{l}\text { Rather, respect for different but complementary skills } \\
\text { can enrich teaching and learning, thus improving the } \\
\text { performance and results of both sexes, e.g. the curric- } \\
\text { ulum can be handled "more practically" by boys and } \\
\text { "more descriptively" by girls. }\end{array}$ \\
\hline $\begin{array}{l}\text { If you "nail" the boys down to a chair, } \\
\text { to books, etc., it will reduce their future } \\
\text { potential. }\end{array}$ & $\begin{array}{l}\text { Let them use their sensorimotor skills during their } \\
\text { childhood and the learning process to meet the great } \\
\text { desire for knowledge. True, it's not just about boys. }\end{array}$ \\
\hline $\begin{array}{l}\text { If you persuade pupils that their results } \\
\text { and work are inadequate and that they } \\
\text { will never master the subject matter, it } \\
\text { will become a reality. }\end{array}$ & $\begin{array}{l}\text { Conversely, if you encourage and persuade pupils } \\
\text { about their abilities and talents, they can easily master } \\
\text { the curriculum thanks to the neurotransmitters gener- } \\
\text { ated by the support. }\end{array}$ \\
\hline $\begin{array}{l}\text { If you remind the pupils of your } \\
\text { childhood and efforts to succeed, you } \\
\text { will place them against you because } \\
\text { the time has changed completely and } \\
\text { today's students are confronted with } \\
\text { a completely different reality. }\end{array}$ & $\begin{array}{l}\text { Be keen on what children and pupils are interested in, } \\
\text { what they want to hear, teach interestingly. By doing } \\
\text { so, we also activate the hippocampus, the "reward } \\
\text { centers" and the production of transmitters. }\end{array}$ \\
\hline
\end{tabular}


INCORRECT APPROACH

CORRECT APPROACH

If you criticize the learner, you make it more difficult for them to succeed.

Even a simple smile can improve the intercortical connectivity of the smiling, but also the one who is being smiled at. And it strengthens positive feelings, self-confidence and motivation to learn.

If you try to "bribe" the children with the promise of later reward, they will increase the resistance to what they had to do before.

If you insist that a child should immediately do their homework, the child will lose time and the joy of learning the new knowledge.
Rather, use the approach to give the children a sense of doing well by a small praise, a smile, etc., that creates a positive connection with the desired work.
Rather, do something to make the brain produce positive neurotransmitters, with the result that it will be easier for learners to do the tasks. If the learner watches a film after doing the homework before going to bed, it will "erase" the acquired knowledge. Music helps to keep the knowledge memorized - this leads to the fixation of knowledge.
If you teach 'black and white', the brain will avoid remembering what is being offered to it.
Connect teaching with your experience. It also provokes pupils to talk. Enhance learning as much as possible to make it interesting - such learning contributes to remembering the curriculum for a longer time.

If you highlight the mistake with a red
colour, the error is "written" into the
neuronal tissue.

Who gets upset when making a mistake, will make mistakes for a long time.

Starting with details, then striving to unite them into a whole and creating an overall view is very difficult, even almost impossible.
It is more beneficial to write the correct answer with the red colour as this image is reproduced in "neuronal tissue".

Those who accept mistakes as something natural and see the possibility of improving, they will see a rapid progress.

Starting with an overall perspective before we come to the details is the way to learn new knowledge more easily.

Source: (Folta-Schoofs, K. \& Ostermann, B. 2019, Schachl 2006).

Emotions during learning do not only mean having a joyful and peaceful atmosphere in the classroom. Emotions are extremely important for education because they affect a production of hormones. Positive emotions, satisfaction, good mood, joy of cognition contribute to the production of dopamine and endorphins, which have a positive impact on cognitive processes, flexibility of thinking, creativity and interest in new ones. On the contrary, fear, anxiety, anger, fears of the future, etc., are conditions that produce increased levels of the stress hormones, i.e. adrenaline, noradrenaline and cortisol.

The reality, however, is that teachers are not always aware of the important functions of emotions in direct educational practice. These are the following: 
- Indicative function - positive emotions awaken and support pupils' interest in the curriculum. The learner acquires new information with interest.

- Function of activation - positive emotions support and develop cognitive processes. Without emotions, learning and interest in the curriculum are "stodgy".

- Function of modulation - positive emotions support the optimal functioning of cognitive processes, they are a "reservoir of energy", but they also mobilize all existing knowledge, making learning easier, more interesting and useful in other activities.

- Metacognitive function - positive emotions help learners to understand themselves, to be able to choose procedures leading to the effective activity, in other words, "learning to understand oneself, learning to learn". (Pekrun, 2006, p. 315-341)

\section{Neuropedagogy and Neurodidactics in Slovakia - Selected Research Results}

In all European countries, this area is extremely emphasized and rapidly developing. This is evidenced by many publications, e.g. in Germany, Poland, Austria, Switzerland.

In Slovakia, neuropedagogy and neurodidactics are developing slowly and lagging behind the European trend. Only a few educators and psychologists deal with it, for instance, Duchovičová (2010) Petlák (2012),

In 2018 and 2019, Petlák conducted research that focused on the relationship between teachers and neuropedagogy. The research results will be published for the first time in this study. This paper focuses on some selected aspects of the research findings.

The survey was conducted based on interviews from the teachers who completed the questionnaire. The selection of the teachers was intentional, so that opinions could be obtained from all over Slovakia. It was attended by the teachers of lower secondary education and teachers of upper secondary education.

The condition was that the teachers were supposed to have taught for more than 10 years, and all of them were graduates of universities. Altogether, 306 teachers participated - 201 women and 105 men. We conducted the interview to objectify the questionnaire views. The interviews confirmed a number of aspects to which we need to pay close attention.

The main objective of the research was to identify:

- self-assessment while applying neurodidactics in the educational process, 
- teachers' opinions on why neuropedagogy in schools is not being developed as needed,

- views on the perspectives of development of neuropedagogy in education.

Our research hypothesis:

We assume that neuroeducation does not attract the necessary attention in the educational process.

We did not notice any significant differences between men and women in the teachers' opinions, nor did they differ according to the type of school, so we evaluate them comprehensively.

Table 2. Knowledge of neuropedagogy and neurodidactics

\begin{tabular}{lcc}
\hline \multicolumn{1}{c}{ My knowledge: } & N & \% \\
\hline no knowledge & 64 & 21.0 \\
\hline little knowledge & 99 & 32.3 \\
\hline average & 65 & 21.2 \\
\hline quite good & 51 & 16.7 \\
\hline excellent & 27 & 8.8 \\
\hline Total & 306 & $\mathbf{1 0 0 . 0}$ \\
\hline
\end{tabular}

The table shows that $78(27+51), 25.5 \%$ of respondents have excellent and good knowledge of neuropedagogy and neurodidactics. We consider this number unsatisfactory, i.e. the one expressing the reality that neurodidactics is not included in the work of our schools and teachers. Also, 64, (21.0\%) of respondents claim that they do not have any knowledge of these theories is remarkable. In the interviews, we found out that most teachers in this category represent primary schools.

Table 3. Where did you learn about neuropedagogy and neurodidactics?

\begin{tabular}{lcc}
\hline \multicolumn{1}{c}{ I learnt about it } & N & $\%$ \\
\hline at various professional seminars & 82 & 26.8 \\
\hline during university studies & 75 & 24.5 \\
\hline while doing the attestation & 74 & 24.1 \\
\hline self-study & 64 & 21.0 \\
\hline cannot say & 11 & 3.6 \\
\hline Sum & 306 & $\mathbf{1 0 0 . 0}$ \\
\hline
\end{tabular}

Teachers' responses show that education and in-service training play an essential role. Younger teachers with some pedagogical experience within 5-8 years most often 
answered that they acquired basic knowledge about neuropedagogy and neurodidactics during their studies. Teachers with longer teaching experience said that they have acquired neuroscience in relation to education at various professional seminars $(82,26.8 \%)$, and $74(24.1 \%)$ have gained this knowledge in another way, i.e. by means of attestation study. Around 64 respondents (20.1\%) gained their own knowledge by self-study. Based on these findings, we notice a positive trend when compared with other European countries, and we started applying neuroscience in education much later, however, we noticed an increasing interest in this subject matter.

Table 4. Using neuropedagogy in the teaching process

\begin{tabular}{lcc}
\hline \multicolumn{1}{c}{ I use neuropedagogy } & $\mathrm{N}$ & $\%$ \\
\hline sometimes & 121 & 39.5 \\
\hline yes - often & 90 & 29.5 \\
\hline never & 86 & 28.1 \\
\hline cannot say & 9 & 2.9 \\
\hline Sum & $\mathbf{3 0 6}$ & $\mathbf{1 0 0 . 0}$ \\
\hline
\end{tabular}

The results are consistent with previous findings on neurodidactics. Thus, out of the total number of respondents $211(90+121), 69.0 \%$ use neuroscience in the teaching process. Although it is not entirely optimal, it suggests the teachers' interest in applying newer approaches in their teaching. However, the number of the teachers who do not use neurodidactic approaches, a total of 95 (31\%), is considered quite high. These findings are a challenge for the teachers themselves, the school management, but also for further education of the teachers, who ought to focus more closely on this subject matter.

We assumed that some teachers do not use neuropedagogical and neurodidactic approaches. However, we did not assume that it would be up to 216 positive respondents, but inclusive to those who said that they only sometimes use neuroscientific approaches. Therefore, we had included the following question into our questionnaire.

Table 5. Why do you only sometimes use neuroscientific approaches in education?

\begin{tabular}{llc}
\hline \multicolumn{1}{c}{ Reasons } & $\mathbf{N}$ & $\%$ \\
\hline lack of knowledge & 97 & 31.7 \\
\hline I prefer traditional teaching & 54 & 15.7 \\
\hline demanding lesson preparation & 48 & 8.8 \\
\hline
\end{tabular}




\begin{tabular}{lll}
\hline \multicolumn{1}{c}{ Reasons } & N & $\%$ \\
\hline yet little experience in schools & 27 & 17.6 \\
\hline cannot say & 80 & 20.2 \\
\hline Total & 306100,0 & \\
\hline
\end{tabular}

Taking into consideration all the answers of the respondents, we can see that they do not have enough professional neuroscientific knowledge, which means they do not trust themselves, and prefer classical teaching that is less demanding in terms of class preparation. Although this is most widespread in our schools, it is true that education based on neuroscience is more demanding, requires a good diagnosis of the learners, and then, there must be the choice of the teaching methods, etc. These findings show that it is necessary to convince the teachers to a significant change in their views, but especially to the new approaches to education with an emphasis on innovation.

Neurodidactics deals with and focuses on several areas in education. We wondered what aspects of neuropedagogy are most important to focus on. We asked ourselves what is the most important thing that one can concentrate on in neuroeducation. We only asked 216 teachers who use neurodidactic approaches. The respondents had the opportunity to formulate their own answers. We divided their answers into the following categories:

Table 6. What neurodidactics do you focus on during your teaching?

\begin{tabular}{llc}
\hline \multicolumn{1}{c}{ I focus on } & N & $\%$ \\
\hline motivation and emotions & 84 & 38.9 \\
\hline cooperation of learners & 56 & 25.9 \\
\hline learning styles of my students & 46 & 21.3 \\
\hline using both hemispheres & 20 & 9.3 \\
\hline something else & 10 & 4.6 \\
\hline Total & $\mathbf{2 1 6}$ & $\mathbf{1 0 0 . 0}$ \\
\hline
\end{tabular}

The structure and the frequency of responses reflect fundamental aspects of neurodidactics. Respondents also identified the order of significance in their answers. The importance of motivation and emotionality in education is one of the fundamental aspects of neurodidactics (e.g. Schachl, 2006). Almost 84 (38.9\%) of respondents commented on this requirement, nonetheless, the importance of both brain hemispheres in the process of education emphasized only 20 (9.3\%) of respondents. 
In $10(4.6 \%)$ responses, there were differences, basically expressing the neuroscientific teaching requirements. For example, "The teaching process would be more interesting, if learning was based on the knowledge and opinions of children." "The teacher must prevent his/her learners from experiencing stress." “The most important thing is to know the learners - then I know what methods I shall choose."

Neuropedagogy and neurodidactics are also referred to as $21^{\text {st }}$ century education. The representatives of these theories even claim that it is a "revolutionary revolution in education". We have researched whether teachers have such an opinion; the findings are as follows.

Table 7. Do you think neuropedagogy and neurodidactics will make a change in the future of education?

\begin{tabular}{lcc}
\hline \multicolumn{1}{c}{ Opinions of the teachers } & N & \% \\
\hline education will change, but not significantly & 189 & 61,8 \\
\hline education will change significantly & 68 & 22,2 \\
\hline education will not change at all & 42 & 13,7 \\
\hline Total & 306 & $\mathbf{1 0 0 , 0}$ \\
\hline
\end{tabular}

The respondents' answers (257) are consistent with the prognosis that education will change. This is a positive finding: teachers are aware of the possibilities and needs of improving education. On the other hand, we must say that only 68 (22.2\%) believe that education will change significantly. We admit that we expected a much higher percentage. The findings show that the so-called traditional (classical) teaching is still perceived as a basis for teaching, and is basically beyond any changes. This is also expressed by the attitudes of 42 (13.7\%) respondents, who are clearly convinced that education will not change noticeably. These results also show the need to pay more attention to innovative approaches in education.

The last open question we asked was about what could contribute to neuroscientific approaches being used more frequently in education.

Teachers answered as follows:

Table 8. What could contribute to more frequent usage of neuroscientific approaches in education?

\begin{tabular}{lcc}
\hline \multicolumn{1}{c}{ Factors } & $\mathrm{N}$ & $\%$ \\
\hline professional seminars for teachers & 118 & 38.6 \\
\hline professional studies in journals & 94 & 30.7 \\
\hline
\end{tabular}




\begin{tabular}{lcc}
\hline \multicolumn{1}{c}{ Factors } & N & \% \\
\hline better initial teacher training & 48 & 15.7 \\
\hline school management interest in innovations & 21 & 6.9 \\
\hline something else & 9 & 2.9 \\
\hline cannot say & 16 & 5.2 \\
\hline Total & $\mathbf{3 0 6}$ & $\mathbf{1 0 0 . 0}$ \\
\hline
\end{tabular}

It is clear from the answers that teachers are interested in the innovation of education with the use of the neuroscientific approach. They would accept professional seminars and specialized studies in journals that would focus on a concrete educational work. In the interviews we found that both professional seminars and professional studies in magazines are a source of inspiration for them. They stressed, however, that these seminars and studies were genuinely aimed at helping teachers - "not theory but also practice" - one respondent stated.

They expressed the opinion that studies are often written for the scientific community and less for the daily work of the teacher. This finding is an incentive for us, university teachers, to offer other teachers, in addition to the expertise, methodological advice and assistance.

This research has confirmed our assumptions. The teachers mentioned several other aspects in the interviews, for instance:

- they explained the lack of knowledge by the fact that when studying this area, it was not up-to-date, and in further education they were more concerned with the subject methodologies rather than with theoretical aspects of education.

- the acquisition of knowledge in this area is not systematic - more systematic attention must be paid to this area in the context of in-service teacher training;

- the examination has shown that non-scientific aspects do not receive systematic attention in direct education and that teachers act occasionally,

- the fact that teachers appreciate the emotional nature of education is satisfying, although not in connection with neuropedagogy; but it sounds promising that they would apply the abilities of newer approaches,

- it is satisfactory that most teachers are aware of and anticipate fundamental changes in education.

The above described research work is a selection of how teachers perceive neuropedagogy, but at the same time a look at what needs to be fundamentally changed and innovated. 


\section{Conclusion}

Innovations that appear in the educational practice in Slovakia are represented by several terms such as neurodidactics, neuropedagogy, brain-compatible learning, and brain-based learning. It is a field that respects a multidisciplinary approach. Neuroscience is a basis for this innovative point of view that focuses not only on brain processes that happen during learning, but also on the lesson planning, respecting and developing learners' individuality. Brain-based learning tries to implement the principles on a neuroscientific base, supporting creativity with the use of variable teaching methods, by strengthening an long-term-memory, to create enriched environment, as well as relaxation and coping strategies.

Learning involves changes of the strength of synapses, the connections between neurons in the gray matter of the brain. Based on the findings of brain research, brain-based teaching provides principles and proposals for effective teaching and learning. The main goal of these principles is to intervene in the pedagogical practice. As a matter of the fact, not all of them are brand new, but they confirm the theories and principles of progressive pedagogy and prove that they are effective. Therefore, an integration of brain-based learning in teacher training is necessary.

As our research has shown, the situation in Slovakia in the area of modernization is slowly improving, and neuroscience views on education are beginning to develop and influence it positively. However, the research has also shown that more attention needs to be paid to the preparation of the future teachers, as well as to teachers who are already in the job as far as the neuroscientific perspective is concerned. In-service teacher training can help significantly in this respect, however, we are convinced that neuroscience and its knowledge can greatly influence the efficiency and the quality of education.

\section{References}

Arnold, M. (2002). Aspekte einer modernen Neurodidaktik. München: Vögel.

Becker, N. (2005). Die neurowissenschaftliche Herausforderung der Pädagogik. Bad Heilbrunn: Klinkhardt.

Caine, R.N., Caine, G. (1997). Unleashing the Power of Perceptual Change: The Potential of Brain-Based Teaching. In: Alexandria, VA: association for Supervision and Curriculum Development. Retrieved from http://www.sedl.org/cgi-bin/mysql/picbib-output.cgi?searchuniqueid $=31$.

Duchovičová, J. (2010). Neurodidaktický a pschodidaktický kontext v edukácii. (Neurodidactic and psychodidactic context of education.) Nitra : PF UKF. 
Dryden, G., Vos, J. (1999). The Learning Revolution. New York: Network Continuum Education.

Folta-Schoofs, K. \& Ostermann, B. (2019). Neurodidaktik: Grundlagen für Studium und Praxis. Stuttgart: Kohlhammer.

Friedrich, G. (2005). Allgemeine Didaktik und Neurodidaktik. Bern: Verlag der Wissenschaften.

Geake, J.G. (2009). The Brain at School: Educational neuroscience in the classroom. New York: Open University Press.

Goleman, D. (2008) Emotional intelligence. New York: Bantam Books.

Hermann, N. (1990). The Creative Brain. North Carolina: Brain Books.

Petlák, E. (2012). Inovácie v edukačnom procese. (Innovation in the educational process.) Dubnica nad Váhom: DTI.

Pekrun, R. (2006). The control-value theory of achievement emotions: Assumptions, corollaries, and implications for educational research and practice. Educational Psychology Review, 18 (4), p. 315-341.

Preiss, G. (1998). Neurodidaktik. Theoretische und praktische Beiträge. Herbolzheim: Centaurus.

Sabitzer, B. (2011). Neurodidactics: Brainbased Ideas for ICT and Computer Science Education. The International Journal of Learning, 18 (2), p.167-177.

Schachl, H. (2006). Was haben wir im Kopf. Linz: Veritas.

Spitzer, M. (2002). Lernen: Gehirnforschung und die Schule des Lebens. Heidelberg: Spektrum Akademischer Verlag.

Ulrich, H. (2006). Neurodidaktik. Grundlagen und Vorschläge für gehirngerechtes Lehren und Lernen. Weinheim: Beltz. 